\title{
Synthesis and Characterization of Thermosensitive Poly(organophosphazenes) with Methoxy-Poly(ethylene glycol) and Alkylamines as Side Groups
}

\author{
Bae Hoon Lee, Young Moo Lee, ${ }^{\dagger}$ Youn Soo Sohn,,$^{+*}$ and Soo-Chang Song ${ }^{\circ}$ \\ Division of Life Science, Korea Institute of Science and Technologu, Seoul 130-650, Korea \\ -Department of Chemical Engineering, College of Engineering, Hanvang Lniversity, Seoul 133-791, Korea \\ ${ }^{ \pm}$Department of Chemistry, College of Natural Sciences, Ewha Homans University, Seoul 120-750, Korea \\ Received November 22, 2001
}

\begin{abstract}
Thermosensitive poly'(organophosphazenes) bearing methoxy-poly (ethylene glycol) (MPEG) and alkylamines as substituents have been sy nthesized and characterized by elemental analysis. NMR spectroscopy. GPC and DSC. All the polymers exhibited crystallinity. which was probably induced by the MPEG side chain of the polymers. All the polymers exhibited the lower critical solution temperature (LCSTs) in the range of 28 to 94 ${ }^{\circ} \mathrm{C}$ depending on several factors such as mole ratio of the substituents. kinds of PEG and alkylamines. The higher content of MPEG and shorter chain length of alkylamines of the polymers afforded the higher LCST. The LCSTs of the polymers exhibited almost concentration-independent behavior in the range of $3-30 \mathrm{wt} \%$ of the polymers in aqueous solutions. The polymers showed the higher LCSTs in the acidic solutions than in the neutral and basic solutions. The ionic strength of the poly mer solution affected the LCST, which decreased with increased $\mathrm{NaCl}$ concentration. The poly mer bearing almost equimolar substitutuents with the $-\mathrm{N}-\mathrm{P}-\mathrm{N}$ - unit has shown the LCST more sensitive to $\mathrm{NaCl}$ and $\mathrm{pH}$ than that with the $-\mathrm{N}-\mathrm{P}-\mathrm{O}$ - unit. The poly mers were found to degrade in acidic solution but be very stable in alkali solution as well as in the buffer solution of $\mathrm{pH} 7.4$
\end{abstract}

Keywords : Thermosensitive poly(organophosphazenes), LCST, Methosy-poly(ethylene glycol) (MPEG). Alkylamines.

\section{Introduction}

Thermosensitive polymers showing a phase transition in response to a temperature change ${ }^{1.2}$ have been extensively studied in the past decade because of their potential applications in many fields such as membranes, ${ }^{3}$ drug delivery systems. ${ }^{4}$ cell culture. ${ }^{5}$ isolation of biomolecules, ${ }^{6}$ and enzyme activity control. ${ }^{7}$ Many thermosensitive polymers exhibit a lower critical solution temperature (LCST). defined as the temperature of the phase transition from a soluble to an insoluble state in aqueous solution. It is presumed that the main mechanism of such a phase transition induced by a temperature change may be a drastic change in the hydrogen bonding between the polymer and water molecules. The LCSTs of the polymers usually vary with the presence of additives such as electrolytes. organic solvents. and surfactants.

Some polyphosphazenes showing the LCST properties have been reported. ${ }^{8-11}$ Tanigani and co-workers have prepared a low molecular weight polyphosphazene with hydroxyl side groups, which exhibits low-temperature water solubility. ${ }^{8}$ On the other hand, Allcock and co-workers have synthesized and characterized a series of alkyl ether based polyphosphazenes, which showed their LCSTs to be influenced by the number of the allyl ether linkage and end

\footnotetext{
${ }^{*}$ Comesponding Authors. Dr. S.-C. Song (e-mail: scsong àtkist.re.kr, Phone: +82-2-958-5123, Fax: +82-2-958-5089). Prof. Y. S. Sohn (e-mail: yssolnutatewhac.kr, Phone: $+82-2-3277-2345$, Fax: $+82-2-3277-2384)$
}

group..$^{910}$ In particular, polyphosphazenes with alkyl ether side chains have been studied as solid polymer electrolyte materials, ${ }^{11}$ which were reported to form complexes with salts such as lithium or silver triflate and have conductivity 100-1000 times higher than the poly (eltlyylene oxide)-lithium salt standard. Recently we have reported biodegradable thermosensitive poly(organophosplazenes) and cyclotriphosphazenes bearing methoxy-poly(etlyylene glycol)(MPEG) and amino acid esters as side groups. ${ }^{i 2.1 .33}$ We could tune the LCSTs of these polymers by controlling the hydrophilic/ hydrophobic balance within the polymer structures.

In this paper. we synthesized and characterized poly(organophosphazenes) bearing methoxy-poly(ethylene glycol) (MPEG) as a hydrophilic group and a alkylamine as a hydrophobic group, and their thermosensitivity. hydrolytic properties and the LCST properties were investigated.

\section{Experimental Section}

Materials. Hexachlorocyclotriphosphazene (Aldrich) was used without further purification. Methoxy-poly(etlylene glycol) (Fluka) with molecular weight of 350 was dried azeotropically with benzene. followed by vacuum drying. and then stored over molecular sieve $4 \AA$. $\alpha$-Amino- $\omega$-methoxy-poly (ethylene glycol) (AMPEG) was prepared using the procedure by Loccufrier et al. ${ }^{14}$ followed by vacuum drying. and then stored over molecular sieve $4 \mathrm{~A}$. Tetrahydrofuran (THF) was dried by reflux over sodium metal and distilled under a nitrogen atmosphere. Butylamine was dried over calcium hydride and distilled. Hexylamine (Acros) and 
octylanine (Acros) were dried over calcium hydride and fractionally distilled.

Instruments. Elemental analysis was carried out with Fisons 1108 CHNS Microanalizer and Polyscan 6IE ICP. ${ }^{1} \mathrm{H}$-NMR measurements were made with a Varian Gemini300 spectrometer operating at $300 \mathrm{MHz}$ in the Fourier transform mode. Proton-decoupled ${ }^{31} \mathrm{P}-\mathrm{NMR}$ spectra were measured with the same spectrometer operating at 121.4 $\mathrm{MHz}$ using triphenyl phosphate as an external standard. Thermal analysis of the polymers was carried out using Dupont DSC 2100 TA Instruments. The sample was heated at a rate of $5^{\circ} \mathrm{C} / \mathrm{min}$ in the range of $-100^{\circ} \mathrm{C}$ to $40^{\circ} \mathrm{C}$. Gel permeation chromatography was carried out using a Waters Associates HPLC/GPC $150 \mathrm{C}$ unit and two Ultrahydrogel columuss (Ultrahydrogel Linear and 250) connected in line at a flow rate of $0.8 \mathrm{~mL} / \mathrm{min}$ at $35^{\circ} \mathrm{C}$. Poly (ethylene oxides) $\left(\mathrm{M}_{\mathrm{w}}: 600.900,1470,7100.12600 .23000,46000.95000\right)$ were used as standards to calibrate the column.

Measurement of LCST. The phase transition of the aqueous polymer solution $(0.1-30 \mathrm{wt} \%)$ was detected visually in a closed glass tube and the temperature was controlled by immersion of the glass tube in an oil bath. The LCST was identified as the temperature at which the solution becane turbid. The LCST was also determined by UV-VIS spectroscopy: The polymer was dissolved in distilled water to a given concentration and the polymer solution was poured into a cell. The cell holder in the spectrophotometer was thermally controlled by heating and cooling. The absorbance at $600 \mathrm{~nm}$ was monitored by increasing the solution temperature. and the LCST was defined as the temperature where $50 \%$ of the absorbance change occurred. The same method was used to determine the LCSTs of the polymers based on the ionic strength of $\mathrm{NaCl}$. The $\mathrm{pH}$ dependence of the LCST was examined in acetic acid/sodium acetate buffer solutions of $\mathrm{pH}$ 2.3.3.2. 4.2. 5.0. 6.0. 7.0 and 8.0.

In vitro hydrolytic degradation study. Hydrolytic degradation of the thermosensitive poly (organophosphazenes) was exanined in neutral. acidic, and basic media. Polymer 3 $(74 \mathrm{mg}$ ) was dissolved in $2 \mathrm{~mL}$ each of $\mathrm{I} \mathrm{N} \mathrm{HCl}, 0.5 \mathrm{M}$ tris buffer of $\mathrm{pH} 7.4$. and $1 \mathrm{~N} \mathrm{NaOH}$. and the solutions were incubated in shaking water bath at $37^{\circ} \mathrm{C}$. Time-dependent hydrolytic behavior of the polymer was determined in terms of molecular weight decrease of the polymer by means of GPC.

Synthesis of [NP(MPEG $\left.)_{\mathbf{x}}(\text { BA })_{2-\mathrm{x}}\right]_{\mathrm{n}}$ (BA : Butylamine). Poly(dichlorophosphazene) was prepared as described previously. ${ }^{15}-16$ The typical synthetic procedure is as follows. The sodium salt of methoxy-poly(ethylene glycol) $\left(\mathrm{M}_{w}=\right.$ 350. MPEG350) was prepared by reaction of MPEG350 (4.8 g. $13.8 \mathrm{mmol}$ ) with 1.1 equivalent of sodium metal in THF $(150 \mathrm{~mL})$ at refluxing temperature for 2 days. After the resultant solution was filtered to remove excess sodiun. the filtrate was added slowly to poly (dichlorophosphazene) ( 2.0 g. $17.3 \mathrm{mmol})$ dissolved in THF $(100 \mathrm{~mL})$. The reaction mixture was stirred for 5 hours at room temperature. Meanwhile. butylamine $(3.0 \mathrm{~g}, 41.5 \mathrm{mmol})$ was dissolved in dry THF $(100 \mathrm{~mL})$ containing 4 equivalent of triethylamine. The polymer solution was added to the butylamine solution. which was stirred for 2 days at $50{ }^{\circ} \mathrm{C}$. The reaction mixture was filtered, and after the filtrate was concentrated. it was poured into $n$-hexane to obtain a precipitate, which was reprecipitated twice in the same solvent system. The polymer product was dissolved in distilled water and dialyzed for 2 days. The dialyzed solution was freeze-dried to obtain polymer $\mathbf{1}$. The other polymers except polymer $\mathbf{8}$ were prepared analogously using different substituents and different mole ratios.

[NP(MPEG350) $\left.)_{0.74}(\mathbf{B A})_{1.26}\right]_{\mathrm{n}}$ (1). MPEG350 $(13.8 \mathrm{mmol})$ and butylamine $(41.5 \mathrm{mmol})$ were used. Yield, $73 \%$. ${ }^{31} \mathrm{P}$ NMR $\left(\mathrm{CDCl}_{3}\right), \delta(\mathrm{ppm}): 20.65 .13 .42 .{ }^{1} \mathrm{H}-\mathrm{NMR}\left(\mathrm{CDCl}_{3}\right) . \delta$ (ppm): $0.8-0.9$ (m. 3H). $1.2-1.3$ (b. $2 \mathrm{H}), 1.3-1.5$ (b. $2 \mathrm{H}), 2.9-$ 3.2 (b, $2 \mathrm{H}$ ). 3.4 (s. $3 \mathrm{H}$ ). $3.6-3.9$ (b. $26 \mathrm{H}$ ), $3.9-4.1$ (b. $2 \mathrm{H}$ ). ${ }^{13} \mathrm{C}-\mathrm{NMR}\left(\mathrm{D}_{2} \mathrm{O}\right) . \delta(\mathrm{ppm}): 71.35 .69 .93 .64 .32,58.37 .41 .02$, $34.10,20.35,13.90$. Elem. anal. (\%) calcd: C. 49.21; $\mathrm{H}$. 9.58 ; N. 8.22 found: $\mathrm{C}, 47.37$ : H, 8.90; N. 8.29 .

[NP(MPEG350) $\left.)_{0.52}(\mathrm{HA})_{1.48}\right]_{\mathrm{n}}(2)$. MPEG350 $(8.6 \mathrm{mmol})$ and hexylamine $(51.8 \mathrm{mmol})$ were used. Yield, $71 \%$. ${ }^{31} \mathrm{P}$ NMR $\left(\mathrm{CDCl}_{3}\right) . \delta(\mathrm{ppm}) ; 20.55$. ${ }^{1} \mathrm{H}-\mathrm{NMR}\left(\mathrm{CDCl}_{3}\right), \delta(\mathrm{ppm})$ : $0.8-0.9(\mathrm{~m}, 3 \mathrm{H}) .1 .2-1.4(\mathrm{~b}, 6 \mathrm{H}) \cdot 1.5-1.6(\mathrm{~b} .2 \mathrm{H}), 2.7-2.9$ (b, $2 \mathrm{H}) .3 .4$ (s. $3 \mathrm{H}) .3 .6-3.9$ (b. $26 \mathrm{H}$ ). $3.9-4.1$ (b, $2 \mathrm{H}) .{ }^{13} \mathrm{C}-\mathrm{NMR}$ $\left(\mathrm{D}_{2} \mathrm{O}\right), \delta$ (ppm): 71.54, 70.13. 64.43, 58.52, 41.68. 32.24 . 27.29, 22.97, 14.13. Elem. anal. (\%) calcd: C. $53.47 ; \mathrm{H}$. 9.91; N. 9.26. found: C, 51.75 : H, 9.41; N. 9.28 .

[NP(MPEG350) $\left.)_{0.81}(\mathrm{HA})_{1.19}\right]_{\mathbf{n}}(\mathbf{3})$. MPEG350 (13.9 mmol) and hexylamine $(41.4 \mathrm{mmol})$ were used. Yield, $70 \% .{ }^{31} \mathrm{P}$ NMR $\left(\mathrm{CDCl}_{3}\right) . \delta(\mathrm{ppm}): 20.31,13.11$. Elem. anal. (\%) calcd: C, 51.65: H, 9.36; N, 6.63. found: C. 51.50; H. 9.54; $\mathrm{N}, 6.64$.

[NP(MPEG350 $\left.)_{1.03}(\mathrm{HA})_{0.97}\right]_{\mathrm{n}}$ (4). MPEG350 (17.3 mmol) and hexylamine $(34.5 \mathrm{mmol})$ were used. Yield, $75 \% .{ }^{31} \mathrm{P}$ NMR $\left(\mathrm{CDCl}_{3}\right), \delta(\mathrm{ppm}) ; 20.11 .13 .12 .{ }^{1} \mathrm{H}-\mathrm{NMR}\left(\mathrm{CDCl}_{3}\right) . \delta$ (ppm): 23.03. Elem. anal. (\%) calcd: C, 50.93: H, 9.14; N, 5.50 . found: C, $51.24 ;$ H. 9.21 : N, 6.14 .

[NP(MPEG350 $\left.)_{1.32}(\mathbf{H A})_{0.65}\right]_{\mathfrak{n}}$ (5). MPEG350 (24.2 mmol) and hexylamine $(20.7 \mathrm{mmol})$ were used. Yield, $69 \% .{ }^{31} \mathrm{P}$ NMR $\left(\mathrm{CDCl}_{3}\right) . \delta(\mathrm{ppm}): 19.52$. 12.40. Elem. anal. (\%) calcd: C. $49.98 ; \mathrm{H}, 8.86 ; \mathrm{N}, 4.10$ found: $\mathrm{C}, 50.00 ; \mathrm{H}, 9.05 ; \mathrm{N}, 4.23$.

[NP(MPEG350) $\left.)_{0.69}(\mathrm{OA})_{1.31}\right]_{\mathrm{n}}(6) . \mathrm{MPEG} 350(12.1 \mathrm{mmol})$ and octylamine $\left(44.9 \mathrm{mmol}\right.$ ) were used. Yield. $79 \%$. ${ }^{31} \mathrm{P}$ NMR ( $\left.\mathrm{CDCl}_{3}\right) . \delta(\mathrm{ppm}) ; 20.55 .{ }^{1} \mathrm{H}-\mathrm{NMR}\left(\mathrm{CDCl}_{3}\right), \delta(\mathrm{ppm})$; $0.8-1.0(\mathrm{~m}, 3 \mathrm{H}), 1.1-1.4(\mathrm{~b}, 12 \mathrm{H}), 1.4-1.6(\mathrm{~b} .2 \mathrm{H}), 2.7-2.9(\mathrm{~b}$, 2H). 3.4 (s. $3 \mathrm{H}$ ). $3.6-3.9$ (b. $26 \mathrm{H}$ ). $4.0-4.4$ (b. $4 \mathrm{H}$ ). ${ }^{13} \mathrm{C}-\mathrm{NMR}$ $\left(\mathrm{D}_{2} \mathrm{O}\right), \delta(\mathrm{ppm}): 71.42,70.03 .65 .55,58.41,41.66 .32 .30$. 29.16, 27.73. 22.86. 14.07. Elem. anal. (\%) calcd: C, 55.13; H. 9.98; N. 7.13, found: C. 54.84; H. 9.34: N, 7.27.

[NP(MPEG350 $\left.)_{1.15}(\mathbf{O A})_{0.85}\right]_{\mathfrak{n}}$ (7). MPEG350 (17.3 mmol) and octylamine $(34.5 \mathrm{mmol})$ were used. Yield. $74 \%$. ${ }^{31} \mathrm{P}$ NMR $\left(\mathrm{CDCl}_{2}\right) . \delta(\mathrm{ppm}):$ 19.7. 12.50. Elem. anal. (\%) calcd: C. $52.36 ;$ H 9.32; N, 4.96 found: C, 52.32; H. 8.97; N, 5.01 .

Synthesis of [NP(AMPEG) $\left.)_{1.04}(\mathrm{HA})_{0.96}\right]_{\mathfrak{n}}$ (8) (HA : hexylamine). AMPEG350 $\left(\mathrm{M}_{w}=350\right)(6.1 \mathrm{~g} .17 .3 \mathrm{mmol})$ dissolved with 4 equivalent of triethylamine in dry THF $(100 \mathrm{~mL})$ was added slowly to poly (dichlorophosphazene) $(2.00 \mathrm{~g} .17 .3 \mathrm{mmol})$ in dry THF $(100 \mathrm{~mL})$. The reaction 
mixture was stirred for 12 hours at room temperature. Meanwhile, hexylamine $(3.5 \mathrm{~g} .34 .5 \mathrm{mmol})$ was dissolved in dry THF ( $100 \mathrm{~mL}$ ) containing 4 equivalent of triethylamine. The polymer solution was added to the hexylamine solution, which was stirred for 2 days at $50^{\circ} \mathrm{C}$. The reaction mixture was filtered, and after the filtrate was concentrated, it was poured into $n$-hexane to obtain a precipitate, which was reprecipitated twice in the same solvent system. The polymer product was dissolved in distilled water, and dialyzed for 2 days. The dialyzed solution was freeze-dried to obtain polymer 8. Yield, $84 \%$. ${ }^{31} \mathrm{P}-\mathrm{NMR}(\mathrm{CDCl}), \delta(\mathrm{ppm}): 20.55$. ${ }^{\mathrm{I}} \mathrm{H}-\mathrm{NMR}\left(\mathrm{CDCl}_{3}\right), \delta(\mathrm{ppm}) ; 0.8-0.9(\mathrm{~m}, 3 \mathrm{H}), 1.2-\mathrm{l} .4(\mathrm{~b}, 6 \mathrm{H})$, 1.4-1.5 (b, 2H), 2.7-2.9 (b, 2H), 3.4 (s, 3H), 3.6-3.9 (b. 26H), 3.9-4.1 (b, 2H), ${ }^{13} \mathrm{C}-\mathrm{NMR}\left(\mathrm{D}_{2} \mathrm{O}\right), \delta(\mathrm{ppm}): 71.53,70.10$, $58.51,40.99,32.22,27.36,22.95,14.15$. Flem. anal. (\%) caled: C. $50.89 ; \mathrm{H}, 9.34 ; \mathrm{N}, 8.34$, found: C, $50.34 ; \mathrm{H}, 9.20$; N. 8.10 .

\section{Results and Discussion}

Synthesis and characterization. The present polymers were synthesized by the synthetic Scheme 1. Poly(dichlorophosphazene) (I) dissolved in THF was reacted with sodium salt of MPEC or AMPEG to yield polymer (II) and an excess amount of alkylamines was then reacted to yield polymer (111). Different copolymers were obtained by using different alkylamines and MPГ:G, and also by changing the mole ratio of the two substituents. The ${ }^{1} \mathrm{H}-{ }^{1 .}{ }^{1 .} \mathrm{C}-$, and ${ }^{31} \mathrm{P}-$ NMR spectra of polymer 1 are shown in Figure 1 . The mole ratio of MPEG and butylamine in polymer 1 was calculated from the integration ratio between the methyl protons of the butylamine and the methoxy protons of the MPEG group appearing at 0.8 and $3.4 \mathrm{ppm}$, respectively. The mole ratio of the MPГG and the alkylamine in other polymers was estimated in the same way. In the ${ }^{13} \mathrm{C}$-NMR spectrum of polymer 1 , the peaks at $71.35,69.93,64.32$, and $58.37 \mathrm{ppm}$ were assigned to MPEG carbons and those at 41.02, 34.10. 20.35 , and 13.90 ppm to butylamine carbons. In the ${ }^{31} \mathrm{P}-$ NMR spectrum of polymer 1 , the sharp peak at $20.65 \mathrm{ppm}$ is ascribed to the phosphorus resonances of the main $-\mathrm{N}-\mathrm{P}^{2}-\mathrm{O}$ unit and a small amount of the $-\mathrm{N}-\mathrm{P}-\mathrm{N}$ - unit. The small peak at $13.42 \mathrm{ppm}$ seems to be ascribed to the phosphorus resonance of the $-\mathrm{O}-\mathrm{P}^{3}-\mathrm{O}$ - unit. Such a result is consistent with the previous work. ${ }^{13}$ From the result of the ${ }^{31} \mathrm{P}-\mathrm{NMR}$ spectra and elemental analysis, the chlorine atom on the polyphosphazene back-bone is presumed to be completely substituted by the substituents of MPEG and alkylamines. The molecular weights of the polymers were measured by GPC using a cosolvent of distilled water and acetonitrile $(4: 1)$ except for those of polymers 2 and 6 which were measured using THF containing $0.1 \%$ TBAB (w/v, tetrabutylammomium bromide). The polymers exhibited the weight average molecular weights in the range of 2.4-9.4 $\times$ $10^{4}$. All the polymers substituted by MPГG and alkylamines were obtained as pale yellow viscoelastic solids, which are fairly soluble in most organic solvents and very soluble in water below their [.CSTS.

All the polymers had glass transition temperatures $\left(T_{\mathrm{g}}\right)$ below room temperature in the range of -75 to $-59{ }^{\circ} \mathrm{C}$, as shown in Table 1. Such results indicate that the high mobility of the phosphazene backbone is not much hindered

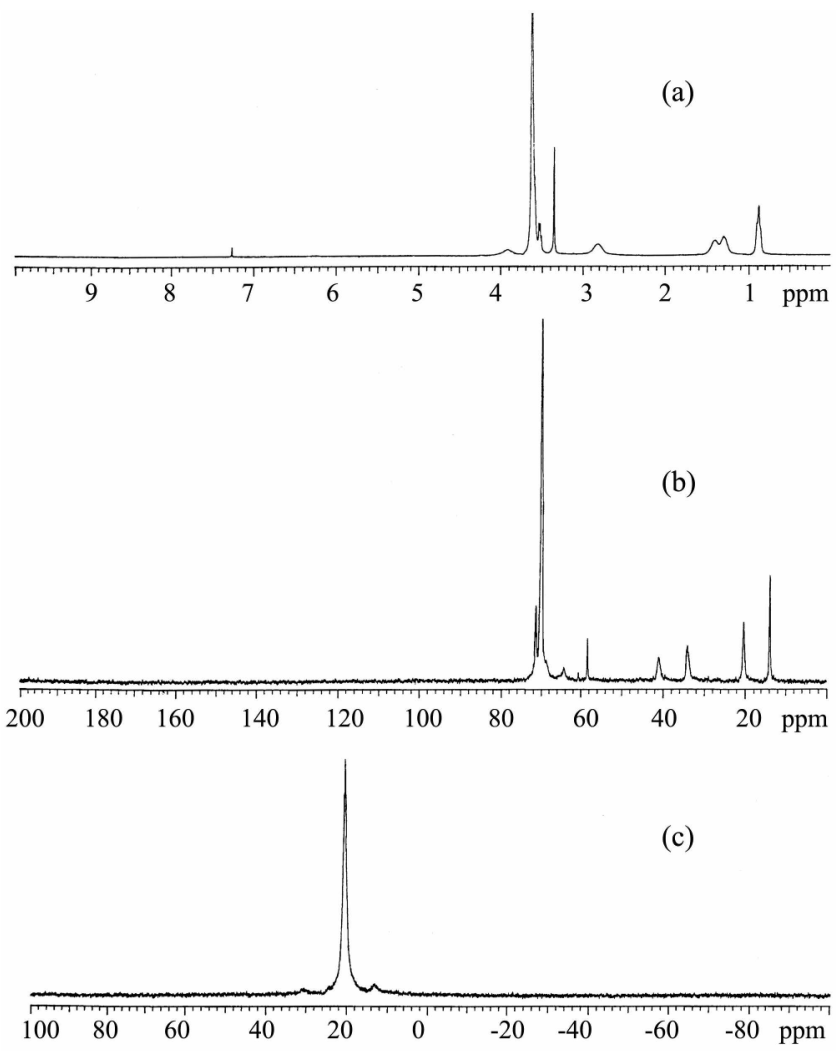

Figure 1. ${ }^{1} \mathrm{H}-\mathrm{NMR}$ (a), ${ }^{13} \mathrm{C}-\mathrm{NMR}$ (b) and ${ }^{31} \mathrm{P}-\mathrm{NMR}$ (c) spectra of polymer 1.<smiles>CP(C)(Cl)(Cl)N=[IH]</smiles>

(I)

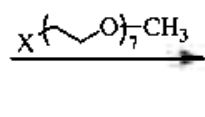

$\mathrm{X}=\mathrm{O}$ or $\mathrm{NH}$<smiles>COCCC[Y](C)(C)(C)(C)N</smiles>

(II)

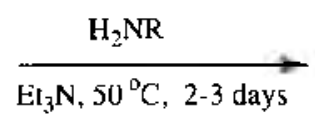

$$
\begin{aligned}
\mathrm{R}= & -\mathrm{CH}_{2}\left(\mathrm{CH}_{2}\right)_{2} \mathrm{CH}_{3} \text { Butyl Amine } \\
& -\mathrm{CH}_{2}\left(\mathrm{CH}_{2}\right)_{4} \mathrm{CH}_{3} \text { Hexyl Amine } \\
& -\mathrm{CH}_{2}\left(\mathrm{CH}_{2}\right)_{6} \mathrm{CH}_{3} \text { Oclyl Amine }
\end{aligned}
$$

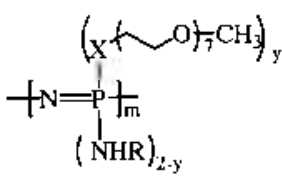

(III)

Scheme 1. Synthetic procedure of thermosensitive poly(organophosphazenes). 
Table 1. Characteristics of Poly(organophosphazenes)

\begin{tabular}{|c|c|c|c|c|c|c|}
\hline Polvmer & Structure & $T_{g}\left({ }^{\circ} \mathrm{C}\right)$ & $T_{\mathrm{ta}}\left({ }^{\circ} \mathrm{C}\right)$ & $\operatorname{LCST}\left({ }^{\circ} \mathrm{C} p\right.$ & $H_{w}\left(\times 10^{-4}\right)$ & $H_{W} / H_{t}$ \\
\hline 1 & 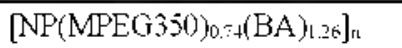 & -73 & -11 & 64 & 2.4 & 4.7 \\
\hline 2 & {$\left[\mathrm{NP}(\mathrm{MPEG} 350)_{0.52}(\mathrm{HA})_{1 .+8}\right]_{\mathrm{n}}$} & -71 & -20 & 31 & 3.5 & 3.6 \\
\hline 3 & {$\left[\mathrm{NP}(\mathrm{MPEG} 350)_{0.81}(\mathrm{HA})_{1.19}\right]_{\mathrm{n}}$} & -71 & -19 & 58 & 4.9 & 3.5 \\
\hline 4 & {$\left[\mathrm{NP}(\mathrm{MPEG} 350)_{1.03}(\mathrm{HA})_{0.07}\right]_{\mathrm{n}}$} & -74 & -16 & 73 & 4.6 & 3.8 \\
\hline 5 & {$\left[\mathrm{NP}(\mathrm{MPEG} 350)_{1.22}(\mathrm{HA})_{0.68}\right]_{\mathrm{n}}$} & -75 & -10 & 81 & 4.6 & 4.1 \\
\hline 6 & {$\left[\mathrm{NP}(\mathrm{MPEG} 350)_{0.50}(\mathrm{OA})_{1.21}\right]_{\mathrm{r}}$} & -71 & -23 & 28 & 3.5 & 4.2 \\
\hline 7 & {$\left[\mathrm{NP}\left(\mathrm{MPEG}(350)_{1.15} \mathrm{OA}\right)_{0.85}\right]_{\mathrm{n}}$} & -59 & -12 & 67 & 9.4 & 4.0 \\
\hline 8 & {$\left[\mathrm{NP}(\mathrm{AMPEG} 350)_{1.04}(\mathrm{HA})_{0.66}\right]_{11}$} & -76 & -16 & 94 & 7.9 & 4.7 \\
\hline
\end{tabular}

"The molecular weights of the polymers were measured by GPC using a cosolvent of distilled water and acetonitrile (4 : 1 ) and those of polymers 2 and 6 were neasured by GPC using THF containing $0.1^{\circ} \circ \mathrm{TBAB}$ (w)

by the substituents. In general. the higher content of MPEG and the shorter chain length of the alkylanine decrease the $T_{\mathrm{g}}$ value. As the MPEG content increased from 0.52 (polymer 2) to $1.32 \mathrm{~mol}$ (polymer 5 ) per unit, the $T_{\mathrm{p}}$ decreased from -71 to $-75{ }^{\circ} \mathrm{C}$. The polymer involving the $-\mathrm{N}-\mathrm{P}-\mathrm{N}$ - unit exhibited the lower $T_{\mathrm{Q}}$ value than the polymers with the $-\mathrm{N}$ P-O- unit: Polymers 4 and 8 showed -74 and $-76^{\circ} \mathrm{C}$. respectively. All the polymers showed the crystallization behavior probably induced by the MPEG side group. Therefore. the melting transition temperature $\left(T_{\mathrm{m}}\right)$ was clearly influenced by the content of MPEG, and the higher content of MPEG increased the $T_{\mathrm{m}}$ value. As the MPEG content increased from 0.52 (polymer 2) to $1.32 \mathrm{~mol}$ (polymer 5) per unit. the $T_{\mathrm{m}}$ value increased from -20 to $-10^{\circ} \mathrm{C}$. The shorter chain length of the alkylamines in the polymers showed the higher $T_{\mathrm{m}}$ value: The $T_{\mathrm{m}}$ values of polymers with butylamine (polymer 1) and with octylamine (polymer 6) exhibited -11 and $-23{ }^{\circ} \mathrm{C}$, respectively. Such a thermal behavior is similar to that of ethylene oxide based polyphosphazene derivatives. $113,1 \hat{j}, 17$

Thermosensitivity. The LCSTs of the present polymers were measured in aqueous solution by a melting point apparatus and UV spectroscopy. As shown in Table 1, most of the polymer solutions exhibited the LCSTs in the range of 28 to $94^{\circ} \mathrm{C}$ depending on the content of MPEG, and kinds of the alkylamines. For the polymers bearing MPEG and hexylanine. the LCST increases with increasing content of MPEG. As the MPEG content increased from 0.52 (polymer 2) to $1.32 \mathrm{~mol}$ (polymer 5) per polymer unit, the LCST increased from 31 to $81^{\circ} \mathrm{C}$. The LCSTs of the polymers was influenced by the kind of alkylamines side group. As expected. the more hydrophobic alkylamine afforded the lower LCST: the LCSTs of polymer 1 with butylamine and polymer 6 with octylamine were 64 and $28^{\circ} \mathrm{C}$, respectively. Interestingly. polymer 8 with the -N-P-N- unit and almost equimolar substituents showed the higher LCST than the corresponding polymer + with the -O-P-N- unit: The LCSTs of polymers $t$ and 8 were 73 and $94{ }^{\circ} \mathrm{C}$, respectively. Such a phenomenon may be understood in terns of different hydrogen bonding ability of the units. The amino group between the polyphosphazene back-bone and AMPEG can be more easily bound by water molecules than the oxygen of MPEG by hydrogen bonding. Thus. the anino group of AMPEG

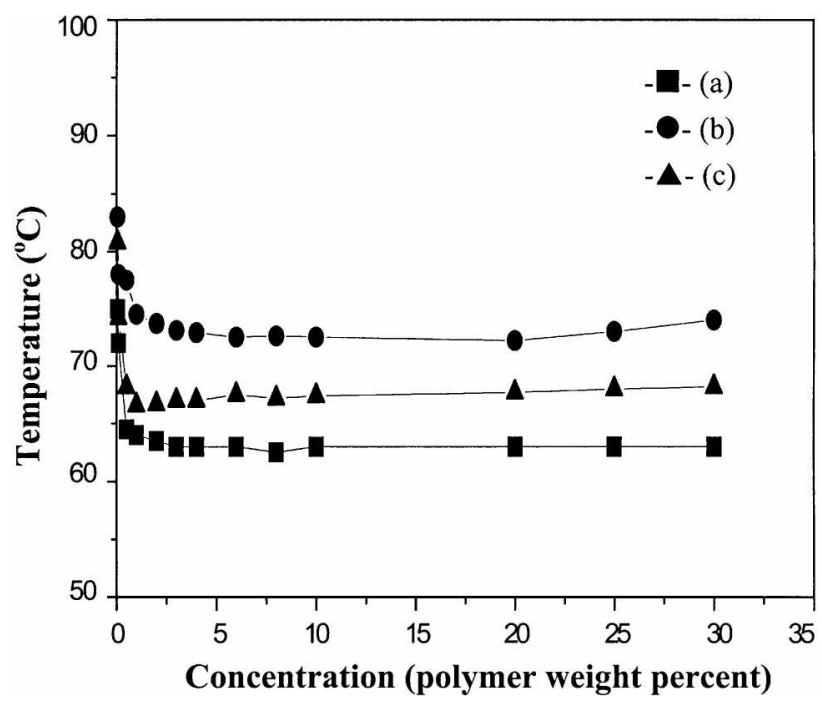

Figure 2. The concentration dependent LCST behaviors of polymer 1 (a), Polymer 4 (b), and polymer 7 (c).

seems to cause a "salting-in" effect."

The concentration dependent LCSTs of the present polymers were determined in the concentration range of $0.1-30$ wt $\%$ of the polymers in aqueous solution and shown in Figure 2 . The polymers were precipitated at all concentrations measured and no significant differences in the concentration-dependent LCST behavior were found among the polymers. The LCSTs of the polymers were found to be almost independent of the concentration in the range of 3-30 wt $\%$ of the polymers but increased at lower concentrations, as was observed for other thermosensitive polymers. ${ }^{10.13}$

We have examined the $\mathrm{pH}$ dependence of the LCST in acetate buffer solutions of different $\mathrm{pHs}$. and the results are shown in Figure 3. The LCSTs of the polymers exhibited "salting in" effects in the acidic media of $\mathrm{pH}<5$, but no significant LCST change was observed in the buffer solutions of $\mathrm{pH}>5$. The LCST of polymer 8 was not detectable at $\mathrm{pH}<4$ and more sensitive to $\mathrm{pH}$ than other polymers at $\mathrm{pH}>5$. This phenomenon also seems to be due to hydrogen bonding ability of the amino group of AMPEG.

In order to examine the salt effect on the LCSTs of the polymers. $\mathrm{NaCl}$ was added to the aqueous solution contain- 


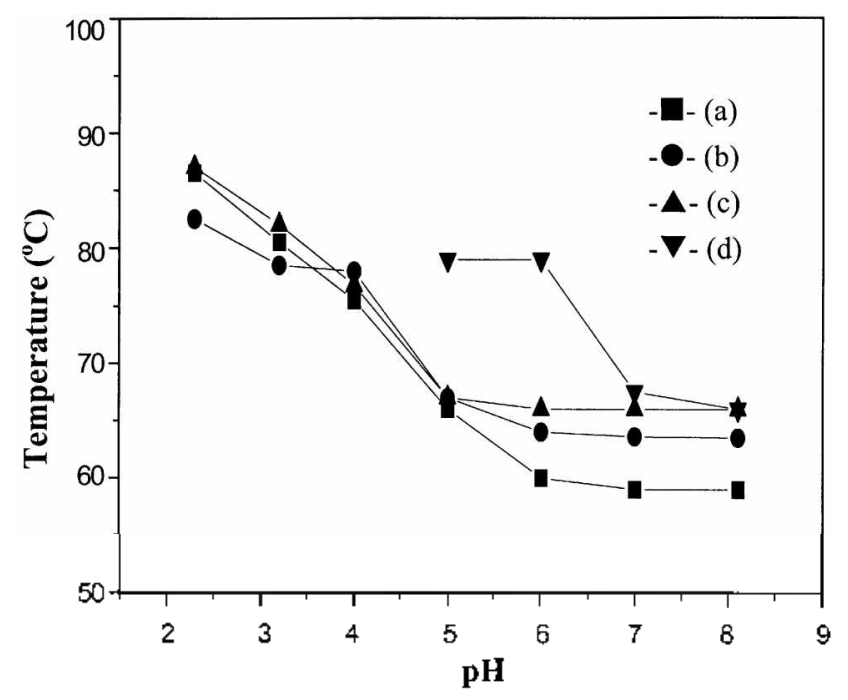

Figure 3. The $\mathrm{pH}$ dependent LCST behaviors of polymer 1 (a), Polymer 4 (b), polymer 7 (c), and polymer 8 (d).

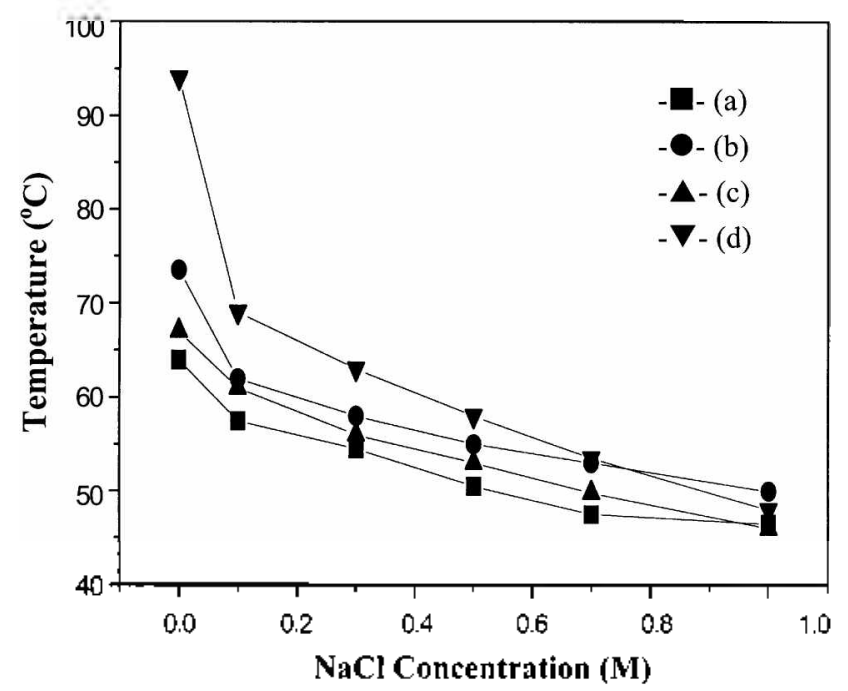

Figure 4. $\mathrm{NaCl}$ effect on the LCST of polymer 1 (a), Polymer 4 (b), polymer 7 (c), and polymer 8 (d).

ing $5 \mathrm{wt} \%$ polymers. The concentration of $\mathrm{NaCl}$ was varied from 0.1 to $1.0 \mathrm{M}$ in the polymer solutions. Addition of $\mathrm{NaCl}$ to the polymer solutions decreased the LCSTs of the polymers as shown in Figure 4. In general, $\mathrm{NaCl}$ was known to play a role in water structure maker, giving a "salting out" effect. The decreasing LCSTs with increasing ionic strength of $\mathrm{NaCl}$ are in accord with the previous results. ${ }^{18}$ Especially, polymer $8\left(\Delta \mathrm{T}_{1, \mathrm{BN} \cdot \mathrm{MM}}=46^{\circ} \mathrm{C}\right)$ showed the larger salting out effect than polymer $+\left(\Delta \mathrm{T}_{1, \mathrm{~b} \mathrm{~N} \text {-(iM }}=23{ }^{\circ} \mathrm{C}\right)$. This is also consistent with the observations that the LCSTs of most hydrophilic thermosensitive polymers is more susceptible to $\mathrm{NaCl}$ than those of hydrophobic thermosensitive polymers. ${ }^{15}$

Hydrolytic behavior. To study hydrolytic properties of the present themosensitive polymers, polymer 3 was dis-

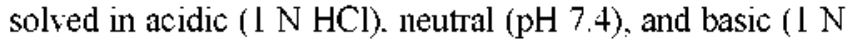
$\mathrm{NaOH}$ ) solutions, which were incubated for 10 days in a shaking water bath at $37^{\circ} \mathrm{C}$. The hydrolytic stability of the

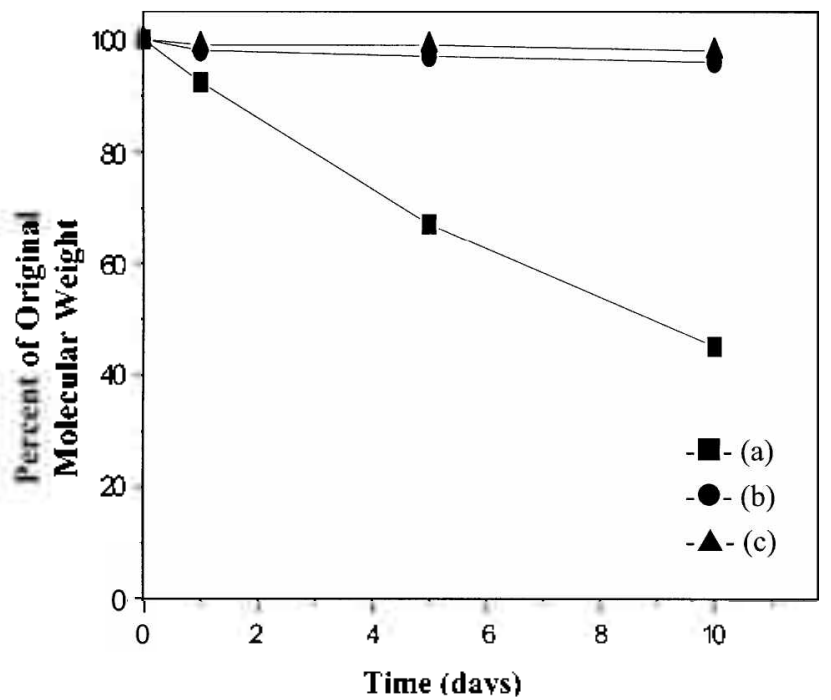

Figure 5 . Time dependent hydrolytic degradation of polymer 3 $1 \mathrm{~N}-\mathrm{HCl}$ (a), $\mathrm{pH} 7.4$ (b), and i N-NaOH (c) solutions.

polymer solutions was monitored in terms of molecular weight changes by GPC. The results are shown in Figure 5. In general, the hydrolytic degradation of poly (organophosphazenes) substituted with amino acid esters was explained in terms of carboxylic acid-catalyzed degradation ${ }^{2 j \cdot 2 \cdot 1}$ On the other hand. the hydrolytic degradation of poly (organophosphazenes) substituted with alkylamines was known to be initiated by back-bone cleavage induced by the protonation of the skeletal nitrogen and the amino group of alky lamines linked to the back-bone. ${ }^{2}$ The present polymers with alkylamines as a side group seem to follow the latter degradation route: Polymer 3 was not degraded in the neutral and basic solutions whereas the polymer was hydrolyzed in the acidic solution.

\section{Conclusions}

A new series of thermosensitive poly(organophosphazenes) bearing MPEG or AMPEG and alkylamines as side groups have been synthesized and their LCST behavior was investigated. The LCSTs of the polymers were affected by kinds of the two substituents. MPEG and alkylamines. and the composition of the two substituents. Generally, the more hydrophilic composition of the polymers showed the higher LCST. The thermosensitive poly(organophosphazene) with AMPEG exhibited the ligher LCST and its LCST was more sensitive to $\mathrm{NaCl}$ and $\mathrm{pH}$ than that with MPEG. Such results seem to be due to the more favorable hydrogen bonding ability of AMPEG. The polymer was hydrolytically degraded in the acidic solution but stable in both neutral and basic solutions.

Acknowledgment. This research was financially supported by the Ministry of the Science and Technology in Korea.

\section{References}

1. Chen. G.; Hotfman. A. S. Nattwe 1995.373, 5. 
2. Teong. B.: Bae, Y. H.: Lee. D. S: Kim, S. W. Nanme 1997, 388. 28 .

3. Shtanko. N. I: Kabanov. V. Y: Apel. P. Y: Yoshida. M.: Vilenskii. A. I. J. Afembrone Sci. 2000. 179. 155.

4. Peppas, N. A.: Langer R. Science 1994, 263. 1715.

5. Recum. A.: Kim. S. W: Kikuchi, A.: Okuhara. M: Sakurai, Y: Okano. T. J. Biomed. Hater Res. 1998, 40.631

6. Monịi. N.: Hothman. A. S. Appl. Biochent. Biotechnol. 1987. It. 107.

7. Park. T. G.: Hotfman. A. S. J. Bionater. Sci. Potwmer Edh. 1993. 5,493 .

8. Tanigani. T: Ono. T: Suda. N.: Sakanaki. Y: Yamaura, K: Matsuzawa, S. Macromolecules 1989. 22. 1397.

9. Allcock. H. R.: Pucher. S. R.: Turner. M.: Fitzpatrick. R. Macrontolecules 1992. 25.5573.

10. Allcock. H. R.: Dudley. G. K. A facrontolecules 1996. 29. 1313.

11. Chen-Yang, Y. W. Hwang, J. I.: Hulang. A. Y. Macromolecules $2000,33,1237$

12. Lee, S. B.; Song S.-C: Jin, J.-L.; Solnn. Y. S. J. Am. Chem. Soc.
2000. 122,8315 .

13. Song. S.-C.: Lee. S. B.: Jit1. J.-L.: Sohn1. Y. S. Macronolecutes 1999. 32.2188.

14. Loccufier. I.: Crommen. J.: Vandorpe. J.: Schacht. E. M fakrontol. Chem. Rapid Commun. 1991. 12. 159

15. Sohn, Y. S.: Cho. Y. H:; Baek, H.-G.: Jung. O.-S. Macromolecules 1995. 28,7566

16. Cho. Y. H.: Baek. H.-G.: Tung. O-S.: Tun. M.-J.: Sohn1. Y. S. Bull Korean Chem. Soc. 1996. 17.85.

17. Vandrope. J.: Schacht. E. Polymer 1996. 37. 3141.

18. Home. R. A.: Almeida. J. P.: Day, A. F.: Yu. N. T. J. Colloid huterf. Sci. $1971,35,77$.

19. Taylor. L. D.: Cerankowski. L. D. J. Polmm. Sci. 1975. 13. 2551

20. Allcock. H. R.: Pucher. S. R.: Scopelianos. A. G. Macromolecules 1994. 27. 1071 .

21. Lee. S. B.: Song. S.-C.: Jin. J.-L.: Sohn1. Y. S. Macromolecules 1999. 32, 7820

22. Allcock. H. R.: Fuller. T. J.; Matsumura, K. Horg. Chem. 1982. 21.515 